\section{Using POSSE Strategy in Teaching Reading Comprehension}

1 Sudarkam R. Mertosono

2 Erniwati

3 Hastini

4 Muhammad Arid

1234 Universitas Tadulako, Palu, Indonesia

\begin{abstract}
This research aims to determine if using POSSE Strategy affects reading comprehension of students majoring in English education of Tadulako University. This is a pre-experimental study using the one group pretest and posttest design. The population was 319 students in academic year 2018/2019. The samples were 35 students selected employing purposive sampling technique. Paperand-pencil method was used when collecting the data with a test as the instrument. The test was administered twice namely pretest and posttest. The data were analyzed statistically using .05 level of significance and 34 degree of freedom. The result showed that after receiving intervention through POSSE Strategy, students scores got improved. In other words, using POSSE Strategy is effective in improving the sampled-students' reading comprehension on any kinds of English text.
\end{abstract}

\section{Keywords}

reading comprehension

POSSE strategy

\section{Ethical Lingua}

Vol. 7, No. 2, 2020

ISSN 2355-3448 (Print)

ISSN 2540-9190 (Online)

Corresponding Email

Erniwati

erniwatizhang@gmail.com

Article's History

Submitted 7 September 2020

Revised 4 October 2020

Accepted 5 October 2020

DOI

10.30605/25409190.214

Copyright (๑) 2020

The Author(s)

This article is licensed under CC BY-NC-SA 4.0 License 


\section{Using POSSE Strategy in Teaching Reading Comprehension}

Reading plays an important role in the process of teaching and learning English either as a second or a foreign language. It becomes one of the macro skills that should be mastered by the students besides listening, speaking and writing. It also becomes the most frequent activity done by the students during or after school hours. By reading students can get information to enrich their skills and knowledge, widen point of view as well as explore ways for expressing hobby or preference. This is in line with Wahyono \& Puspitasari (2015) who state that reading is an important language skill to explore information as references and additional materials for their study.

Reading is a process of communication between writers and readers. Reading is not only about spelling letters in a text, but it is also about understanding its meaning to get the messages across as expressed by the writer. The process of communication will be taking place when the readers obtain the purpose and meaning of the text in the form of facts, ideas and feelings. Therefore, in order to be an effective reader, readers need to understand the text-known as reading comprehension.

Reading comprehension can be defined as a process of gathering information from a text to construct meaning using readers' background knowledge. It is a very complex process because negotiation and interaction between ideas and thoughts of writers and eyes of readers occur while reading. Besides, in order to be able to understand the text, the readers need to have not only sufficient linguistic competence, they also need to have the so-called cognitive and intellectual competence.

Reading comprehension is never easy for students. Data of students individual score who took diagnostic pretest for TOEFL reading comprehension indicated that almost all students 'failed' with an interval percentage of mastery level of 0\%-39\%. Some factors affecting the students failure included low vocabulary mastery and lack of background knowledge on reading topics. Another is closely related to reading strategies.

For that reason, a good strategy is required to help students improve their reading comprehension as well as make them an effective reader. POSSE Strategy enables students to achieve both goals. POSSE stands for Predict, Organize, Search, Summarize, and Evaluate. This strategy is based on the three phases of reading activity, namely pre-reading, whilereading and post-reading. This research aims to determine if using POSSE Strategy affects student reading comprehension on any kinds of English text.

Like listening, reading is a receptive skill. Nurgiyantoro (2012:39) states, "Reading is a skill to get, to understand, and to respond to information expressed by others through writing." Moreover, reading can be defined as a process of interpreting messages from writer to readers presented in the form of words, sentences and paragraphs (Nurhadi, 2016). In instructional context, reading refers to a process of making meaning through some activities shown in before, during, and after reading the text (Wahyono (2019). Thus, reading means an active process done by readers to get the meaning across from the written message. 
Reading activity should be intended for fostering reader's ability in reasoning. It is a process of combining information obtained from the text with knowledge and opinions of readers. There are three main things involved in reading comprehension, which include; first, readers' prior knowledge and experience, second, connection between the reader's prior knowledge and experience and the text they are going to read, and the last, process of acquiring meaning in accordance with the reader's view (Somadyo, 2011). Therefore, a reader cannot be said to understand a text before he is able to make a connection between new information found in the text and his prior knowledge. To put it in other way, reading comprehension will always be a priority in teaching and learning of reading skills.

Reading comprehension is meant to get information stated explicitly and implicitly in a text. There are four levels of reading comprehension: literal comprehension, interpretative or inferential comprehension, critical comprehension and creative comprehension. A reader is said to have reached literal comprehension level when he can find explicit information from the text. Although literal comprehension is the lowest level of reading comprehension, it helps readers understand the text as a whole. On the contrary, when readers are able to find implicit information from the text and integrate it into their prior knowledge to make assumption or hypothesis, they are considered to have been in the level of inferential comprehension. Next, critical comprehension level relates to reader's ability in evaluating the content of a text by comparing and contrasting information found in the text to their prior knowledge and experience. In this level of reading comprehension, readers will use cognitive dimension integrated with their imagination to get a new picture beyond what is presented in the text.

When teaching reading comprehension to students, teacher should follow three stages of activities. First is pre-reading activiy. Teacher prepares students to get involved in reading activity through some activities such as activate students background, determine the reading objectives, make prediction and questions as well as introduce keywords of the text. Second is while-reading activity. Teacher will prepare students to read the text, help them focus on aspects of text in order to get better understanding of the text they are reading. Last is postreading activity. Teacher prepares students to draw conclusions from the content of the text and to make a connection between reading and writing through several enrichment activities.

Heilman, Blair, \& Rupley (2002) divide reading comprehension into four levels as described below: 1) Literal level, this is the lowest level of comprehension in which the readers can recall/repeat relevant information explicitly stated in the text. Abilities refer to this level are vocabulary knowledge, recalling ideas, understanding of grammar clues, etc. 2) Interpretative level; the readers understand the facts that are not directly stated in the text by making inferences of what the text means. Information stated in the text is used as the clues to determine implied information. Abilities relate to this level are reasoning and making inferences. 3) Critical level The readers analyze, judge and critique information or ideas stated in the text. Explanation and argument are required to support judgment or justification made. Besides, the readers are supposed to decide their stance on issues and situation presented in the text. Reacting to information in the text, analyzing and evaluating the quality of information are abilities required in this level. 5) Creative comprehension; This is the highest level of comprehension. It requires the readers to get involved with information in the text when formulating and rethinking ideas. Through this level the readers can determine the writer's point of view, purpose, tone, message, etc. This level also allows the readers to put their own knowledge, views and values. Knowledge of emotional response and knowledge of form, style and structure of the response are abilities required in this level. 
POSSE is a reading comprehension strategy developed by Carol Englert and Troy Mariage in 1991. This strategy covers several reading comprehension techniques that can help readers to get meaningful model of learning by comparing what is known to what is going to learn (Aprilia, 2015). According to Englert \& Mariage (1991), POSSE Strategy enables readers to find information from all types of text.

POSSE is considered to be 'good' strategy for teaching reading comprehension. It has several benefits as follows:

1. Students have opportunity to get new information by activating and connecting their prior knowledge with the topic discussed.

2. Students are able to get new information and practice their reading experience using advance organizers.

3. Students are able to make a conclusion to a new topic using their prior knowledge.

4. Students are allowed to share the information to their groups.

5. Students have chance to do monitoring and self-assessment by comparing their prior knowledge before and after getting the new information. They are also able to compare the result of concept diagram made on prediction stage with information obtained after reading the text.

6. Students have opportunity to learn how to summarize important information of the text. This activity helps students improve their comprehension of the text and vocabulary mastery as well.

Yet, just like other teaching strategies, POSSE has its own drawbacks that the teachers need to consider before applying it in their own classroom practice. Englert \& Mariage (1991) explains that POSSE Strategy has two pitfalls as summarized below:

1. This strategy enables students to give wrong information or input to other students in discussion.

2. It is difficult for teacher to monitor the discussion in a big class; thus, the wrong information may spread and develop among students.

\section{Teaching Reading Comprehension through POSSE Strategy}

There are five stages of using POSSE Strategy in teaching reading comprehension. Each stage covers one main activity. It means, there are five main activities that the students have to complete when applying this strategy. Two activities are completed in the stage of before reading (predict and organize), while three activities are completed in the stage of during and after reading (search, summarize, evaluate). The five stages are described below.

\section{Predict}

Brainstorming is the main key of this stage. Students work in group to predict the content of the text through title, picture, or keywords. They will be guided to activate their prior knowledge in this stage (Klinger, Vaughn, \& Boardman, 2007). 


\section{Organize}

Student groups will organize and arrange ideas from previous stage using concept map or graphic organizer in this stage. The teacher may discuss what new ideas the students have learned about the topic.

\section{Search}

Student groups will read the text to ensure their prediction and to find main ideas in the text. Also, they will look for new or unfamiliar words in the text. Aprilia (2015) states that through this stage the students can confirm their initial prediction by comparing ideas or words they find in the text.

\section{Summarize}

Student groups will determine main ideas of each paragraph in this stage. Later, the main ideas will be put together into a summary of the text or reading passage.

\section{Evaluate}

Student groups will do four things in this stage. First, the students will ask the teacher all things related to the text or reading passage. The teacher can provide a template to help students develop questions about main ideas. Second, each group compares the concept map or concept diagram they prepare as part of the discussion. Next, the students write unfamiliar words or phrases that require furher explanation from the teacher. Last, students will fill out the worksheet (Jameel, 2017).

\section{Method}

This research applied pre-experimental design called the one-group pretest-posttest design. The samples were 35 saphomores majoring in English Education at Tadulako University selected using purposive sampling technique. Intervention using POSSE Strategy was given in six meetings. To collect the research data, paper-and-pencil method was applied with tests as the instrument. The test was taken from standardized English language test like IELTS.

Three steps were taken when collecting data. First, the sampled students were pretested in order to find out their prior knowledge on reading comprehension. The test was administered for 60 minutes. Second, the students were taught using POSSE Strategy. This intervention was administered in six meetings, 100 minutes per meeting. Last, the students were posttested to determine the effect of the strategy applied on the students' reading comprehension.

The students were provided with a reading passage during the tests with 14 comprehension questions to be completed in 30 minutes. Each correct answer was scored one; thus, the score total would be 14 .

Data of the pretest and the posttest were tabulated and analyzed statistically using the formulas suggested by Gay, Mills, \& Airasian (2006) as such. Firstly, students individual scores were tabulated. Having tabulated the students individual scores on both tests, mean score was analyzed to reveal the significant difference between the tests-the pretest and the 
posttest after the intervention using POSSE Strategy. Last, analysis of t-counted was done to ensure if hypothesis is accepted or rejected.

Table 1. Score Range Classification

\begin{tabular}{cc}
\hline Range & Classification \\
\hline $12-14$ & Excellent \\
\hline $9-11$ & Good \\
\hline $6-8$ & Fair \\
\hline $0-5$ & Poor \\
\hline
\end{tabular}

\section{Results}

Table 2. Students' scores and classification on pretest and posttest

\begin{tabular}{|c|c|c|c|c|}
\hline Student & $\begin{array}{l}\text { Score of } \\
\text { pretest }\end{array}$ & Classification & $\begin{array}{l}\text { Ccore of } \\
\text { posttest }\end{array}$ & Classification \\
\hline 1 & 7 & Fair & 13 & Excellent \\
\hline 2 & 5 & Poor & 9 & Good \\
\hline 3 & 6 & Fair & 11 & Good \\
\hline 4 & 7 & Fair & 9 & Good \\
\hline 5 & 5 & Poor & 9 & Good \\
\hline 6 & 5 & Poor & 8 & Fair \\
\hline 7 & 5 & Poor & 9 & Good \\
\hline 8 & 7 & Fair & 9 & Good \\
\hline 9 & 3 & Poor & 9 & Good \\
\hline 10 & 5 & Poor & 7 & Fair \\
\hline 11 & 6 & Fair & 10 & Good \\
\hline 12 & 5 & Poor & 9 & Good \\
\hline 13 & 8 & Fair & 12 & Excellent \\
\hline 14 & 3 & Poor & 8 & Fair \\
\hline 15 & 5 & Poor & 9 & Good \\
\hline 16 & 6 & Fair & 12 & Excellent \\
\hline 17 & 4 & Poor & 10 & Good \\
\hline 18 & 6 & Fair & 11 & Good \\
\hline 19 & 5 & Poor & 9 & Good \\
\hline 20 & 5 & Poor & 8 & Fair \\
\hline 21 & 5 & Poor & 9 & Good \\
\hline 22 & 4 & Poor & 8 & Fair \\
\hline 23 & 5 & Poor & 8 & Fair \\
\hline 24 & 3 & Poor & 7 & Fair \\
\hline 25 & 5 & Poor & 10 & Good \\
\hline 26 & 5 & Poor & 13 & Excellent \\
\hline 27 & 6 & Fair & 9 & Good \\
\hline 28 & 6 & Fair & 9 & Good \\
\hline 29 & 7 & Fair & 11 & Good \\
\hline 30 & 5 & Poor & 9 & Good \\
\hline 31 & 5 & Poor & 9 & Good \\
\hline 32 & 8 & Fair & 14 & Excellent \\
\hline 33 & 3 & Poor & 7 & Fair \\
\hline 34 & 5 & Poor & 10 & Good \\
\hline 35 & 3 & Poor & 8 & Fair \\
\hline
\end{tabular}

The above table 2 shows that all of the students' scores were categorized as 'poor' and 'fair' on the pretest. However, after they were given intervention using POSSE Strategy, none of them scored 'poor' and thus no longer appeared in the list. Instead, five students were categorized as 'excellent', 21 were categoried as "good" and the rest nine students were 
categorized as 'fair'. It means, there is a significant improvement of the student reading comprehension on the posttest.

Table 3 indicates that the mean deviation of the posttest was higher than the mean deviation of the pretest $(9.50>5.23)$. Difference in means between the pretest and the posttest was 4.27. Clearly, the difference between means is highly significant.

Table 3. Mean and Standard Deviation on the Pretest and the Posttest

\begin{tabular}{cll}
\hline Variable & Mean Score & Standard Deviation \\
\hline Pretest & 5.23 & 1.33 \\
Postest & 9.5 & 1.72 \\
\hline
\end{tabular}

Table 4. Differential test results (test $t$ )

\begin{tabular}{ll}
\hline $\mathrm{N}$ & 35 \\
$\mathrm{df}(\mathrm{N}-1)$ & 34 \\
& 4.26 \\
$\mathrm{SS}$ & 56.69 \\
$\mathrm{SD}$ & 1.29 \\
$\mathrm{t}-\mathrm{counted}$ & 19.36 \\
$\mathrm{t}$ critical one-tailed & 1.691 \\
\hline
\end{tabular}

The table shows that the value for $t$ with $34 \mathrm{df}$ was 19.36, while the critical $\mathbf{t}$ value $(p=0.05)$ for $34 \mathrm{df}$ was 1.691. It means, the t-counted value is higher than the t-table value. As the calculated $t$ value exceeds the tabulated $\mathbf{t}$ value, the research hypothesis is accepted. In other words, POSSE Strategy positively affects students reading comprehension.

\section{Discussion}

The objective of this research is to find out if using POSSE Strategy affects students' reading comprehension of any kinds of English texts. Data analysis showed that there was a significant difference on the students' reading comprehension before and after the intervention. While 66 percent students got 'poor' category on the pretest, none got such category on the posttest. Instead, 14 percent students were in the 'excellent' category, 60 percent got 'good' category and 26 percent got 'fair' category. This findings clearly answer the research question that using POSSE Strategy is effective in improving students reading comprehension in any kinds of English text.

POSSE Strategy effectively improves student reading comprehension due to its explicit strategy instruction. Steps provided in POSSE Strategy enable students to be effective readers. Clearly, this strategy allows teacher to introduce some cognitive strategies, such as activating, organizing, searching, summarizing, and monitoring-clarifying, to students. When these strategies are directly taught to students, their reading comprehension can be better.

Furthermore, applying POSSE Strategy promotes informal cooperative learning among students. It allows them to work together to achieve learning goals. When the students of different level of ability do some reading activities, their comprehension on the text read is improved. In other words, cooperative learning as part of the POSSE Strategy helps the students' cognitive process. 
However, the students may get difficulty to accomplish the tasks of each step of the POSSE Strategy if they do not know or unfamiliar with the cognitive strategies like searching, organizing, summarizing, etc. For that reason, consideration of students' level of ability needs to be given before applying the strategy. The students may also fail in getting information or messages of the text if the teacher does not guide them to apply steps of the POSSE Strategy properly. The students undeniably take some time to organize the information stated in the text, while at the same time they do not have much time to familiarize themselves with the text. Therefore, the teacher should prompt the students to implement the steps properly.

\section{Conclusion}

Using POSSE Strategy is effective in improving the sampled students' reading comprehension in any kinds of English text. Data analysis shows that the difference in means between the pretest and the posttest (3.87) and the difference in values between the calculated $t(19.36)$ and the tabulated $\mathbf{t}$ (1.691) are highly significant. Therefore, using POSSE Strategy in the teaching of reading comprehension brings positive impact on the sampled students' reading comprehension.

\section{Acknowledgment}

N/A.

\section{References}

Aprilia, N. (2015). Improving Reading Comprehension of the Eighth Grade Students at SMP N 6 Yogyakarta through POSSE Strategy in the Academic Year of 2014/2015.

Englert, C. S., \& Mariage, T. V. (1991). Making Students Partners in the Comprehension Process: Organizing the Reading "POSSE". Learning Disability Quarterly, 14, 123-138.

Gay, L. R., Mills, G. E., \& Airasian, P. (2006). Educational Research: Competencies for Analysis and Application ( $8^{\text {th }}$ ed.). Upper Saddle River, NJ: Pearson Education, Inc.

Heilman, A. W., Blair, T. R., \& Rupley, W. H. (2002). Principles and Practices in Teaching Reading $\left(10^{\text {th }}\right.$ ed.). London, UK: Pearson.

Jameel, A. S. (2017). The effectiveness of P.O.S.S.E Strategy on Improving Reading

Comprehension of the EFL University Students. International Journal of English

Literature and Social Sciences, Vol. 2 (4), pp. 123-133.

Klinger, J., Vaughn, S., \& Boardman, A. (2007). Teaching Reading Comprehension to Students with Learning Difficulties. New York: The Guilford Press.

Nurgiantoro, B. (2012). Penilaian Pembelajaran Bahasa. Jogyakarta: BPFE.

Nurhadi. (2016). Teknik Membaca. Jakarta: Bumi Aksara.

Somadyo, S. (2011). Strategi dan Teknik Pembelajaran Membaca. Yogyakarta: Graha IImu.

Wahyono, E., \& Puspitasari, D. (2015). Students' Need Analysis of English Reading Skills for Academic Purposes. International Conference on Teacher Training and Education.

Sebelas Maret University, Indonesia.

Wahyono, E. (2019). Correlation between students' cognitive reading strategies and reading comprehension. Jurnal Studi Guru dan Pembelajaran, 2(2), 256-263.

https://doi.org/10.30605/jsgp.2.3.2019.61 